Printed by: hidayah_rahman@iium.edu.my. Printing is for personal, private use only. No part of this book may be reproduced or transmitted without publisher's prior permission. Violators will be prosecuted.

\title{
Readiness and participation of local community for river-based tourism development in Sabak Awor, Muar, Johor
}

\author{
S.N.A. Zuhairi, N.H.A. Rahman, S.A. Abas, S.S.M. Sawari \& S.A.A. Latif \\ International Islamic University Malaysia, Johor, Malaysia
}

R.M. Wirakusuma

Universitas Pendidikan Indonesia, Bandung, Indonesia

\begin{abstract}
The research on river-based tourism in terms of community participation and readiness for river-based tourism development is still limited, especially in the Malaysian context. For instance, this study intends to explore the readiness and participation of the local community for river-based tourism development in Sabak Awor, Muar. A qualitative approach is adopted to this study on the readiness and community participation for river-based tourism development in Sabak Awor village, Muar through the semi-structured interview questions. A total of five residents have participated in the interview. The analyses have yielded into five main findings, namely the low level of knowledge influence local's readiness, tourism resources presents the creation of tourism activities in the area, low involvement in participation in decision-making process and planning, high involvement of the community in tourism operation and management, and benefits gained in terms of economic, infrastructure of the village, and personal development of the community. This study contributes to the planning and development of river-based tourism activities. The findings are beneficial for the management of the key players in the tourism industry to promote the potential of Sabak Awor village as a new tourism destination, specifically for river-based tourism.
\end{abstract}

Keywords: community readiness, community participation, river based tourism, Muar River, tourism planning and development

\section{INTRODUCTION}

The tourism industry is considered a pivotal source of economic growth in the world economy. Hence, local community support for tourism is necessary to ensure commercial, socio-cultural, political, and economic sustainability (Hanafiah et al. 2013). River-based tourism provides various tourism activities that are yet to be explored by the local's perspective. According to Prideaux and Cooper (2009), the main tourism resource is the river as it provides a great ambience for recreational opportunities, waterfront landscapes, transportation, and an essential source of living such as water. In Indonesia, the river is one of the recreational resources that has the potential for water sport (Rahmafitria et al. 2017). In addition, Shakiry's (2007) study has supported that River tourism is a worthy market because it could contribute to the local economies. For instance, along the riverbanks, potential jobs could be created especially in tourism activities such as cruise ships, pleasure boats, and parks which include other recreational facilities. It is possible that by implementing tourism projects and activities along the river would potentially give benefits to the locals around the area.

Based on the previous literature, studies that focused on river-based tourism are still limited even though there are a few studies had acknowledged the impact of the Muar river towards the local community (Abu Samah et al. 2013). Precisely, an interesting study of the relationship of the river in Muar that had been conducted by Abu Samah et al. (2013) has revealed there was only a 
Printed by: hidayah_rahman@iium.edu.my. Printing is for personal, private use only. No part of this book may be reproduced or transmitted without publisher's prior permission. Violators will be prosecuted.

minority of Muar River's community that still has a strong relationship with Muar River in terms of fulfilling their basic needs and also their source of income. This has shown that the Muar river has less influence on the community. He further explained that the locals agreed to participate in river development despite the low influence of the river (Abu Samah et al. 2013). He noted that the main issue that needs to be addressed is the participation of communities for river-based tourism in rural areas (Abu Samah et al. 2013). A lot of concerns raised in terms of the cooperation from local leaders to be involved with the local communities of Sabak Awor, Muar for the river-based tourism development project. Therefore, this paper aims to explore the local community readiness and participation for river-based tourism development in Sabak Awor Village, Muar, Johor, Malaysia.

\section{LITERATURE REVIEW}

\subsection{Understanding the river based tourism}

According to Prideaux and Cooper (2009), the rivers are not only one of the major tourism resources, but it also provides spectacular attractions and natural settings, providing recreational opportunities, as well as the waterfront landscapes. It can also be a means of transportation. In this era, there is increasing use of the rivers as tourism resources either as an attraction, a transportation corridor, or as well as the main source of water.

In Malaysia, Nasarudin and Bahar (2013) have discovered that the Pergau River in Kelantan is an example of river-based tourism that own various potentials that can be developed. Among the activities that can aid in its potentials are including the adventure tourism activities. These activities include kayaking, water rafting, river cruise, and other related river-based activities (Kunjuraman et al. 2019). Moreover, the river which is famous for ecotourism activities in Malaysia that have been polluted include Sungai Langat, Sungai Segget, Batang Rajang and Sungai Melaka (Asyraf et al. 2013). Asyraf et al. (2013) stated that rivers are mainly used for transportation purposes in previous years, however, currently, the river is known as ecotourism destination as it offers wide-ranging ecotourism activities dedicated for those who love nature and extreme activities. The activities offered are cruising tours, watching the wildlife and observation, swimming, picnicking, and kayaking. There are two major issues related to river tourism. First, river pollution and bad water quality issues have led to less river-based tourism activities offered. Hence, the polluted rivers will affect people's health, nation economy, marine life, and especially to the environment (Asyraf et al. 2013). Secondly, the study has emphasized that the local community has less awareness of river protection and had contributed to the major reason for river pollution (Asyraf et al. 2013). Therefore, this study is conducted due to these two major issues concerning the river tourism planning and development in Malaysia, especially in the context of the Muar River.

According to Rahman et al. (2020), there are various opportunities for tourism products along the Muar River that include recreational, cultural heritage, community-based tourism, and entertainment. In addition, Muar is still lacking in terms of river-based tourism which this argument has been stated in a previous study by Hamdi et al. (2019) whereby there are two tourism attraction parks in Muar which are Tanjung Emas and Tanjung Ketapang. These two places offered great views and have a unique history, but these two locations are only being used for casual walkway and joggers' lane. In fact, Muar is blessed with its beautiful and wide river that offers a scenic view of mangrove species, and parts with majestic buildings only cater to a simple river cruise activity (Hamdi et al. 2019). Hence, this study will add the body of knowledge in exploring the potential tourism products through discovering the local community readiness and participation in river-based tourism product development for Muar River.

\subsection{Overview of Sabak Awor village in Muar, Johor}

Sabak Awor is recognized as the oldest village in Muar district, Johor, Malaysia. Sabak Awor Village is located along the riverside and can be accessed with vehicles. Based on the report of 
Printed by: hidayah_rahman@iium.edu.my. Printing is for personal, private use only. No part of this book may be reproduced or transmitted without publisher's prior permission. Violators will be prosecuted.

Jawatan Kuasa Keselamatan dan Kemajuan Kampung (JKKK Report 2015), the population of Sabak Awor Village is 8890 people in 2015 which had been recorded by the previous headman, Tuan Hj Deris. There is a multiracial community in this village which are, Malay, Chinese, and Indian. There is six areas in Sabak Awor which are Kampung Sabak Awor Dalam, Kampung Sabak Awor Luar, Kampung Jalan Ismail, Kampung Jalan Batu, Kampung Jalan Bakariah, and Kampung Parit Setongkat (JKKK Report 2015).

River-based tourism development in Sabak Awor, Muar is still lacking. However, Sabak Awor village has the potential to be known as river-based tourism attraction because the river has a lot to offers. Sabak Awor village has various tourism activities ranging from agrotourism, nature tourism, and gastronomy tourism (JKKK Report 2015). However, the lack of awareness in developing the village as rural tourism development has contributed to the failure of tourism planning in that area. According to JKKK Report (2015), Sabak Awor has great natural resources to be offered to the tourists such as fireflies watching, fishing tours, boat tours, and the famous "Ikan Bakar" restaurants that managed to attract visitor from outside Muar area to come and experience its fresh seafood. The local community plays an important role to ensure that the tourism planning development in Sabak Awor is successful because the locals will gain benefits from these tourism activities. However, a lot of efforts need to be done in ensuring the sustainability of the tourism attractions and its resources in the village are well maintained. The local community together with stakeholders needs to work together in developing this place as a river-based tourism destination. In fact, Sabak Awor has a variety of amazing natural resources to offer and has huge potentials to be developed as a new tourism attraction. Therefore, this paper intends to explore the readiness and local community participation for river-based tourism development in Sabak Awor village, Muar, Johor, Malaysia.

\subsection{Community participation and readiness models in tourism}

This study has adopted the Thammajinda's (2013) Community Participation Model in which this model was developed from McIntosh, Goeldner, and Ritchie's (1986) study model. Based on these two models, there are three aspects that related to the local community participation. First, the involvement of the local community in decision making. Second, the involvement of the local community in tourism operation and third, the involvement of the local community in benefits to tourism.

Timothy's (2002) study has identified that public participation in decision-making is related to the community involvement in tourism development on deciding the goals and having their voice heard in the organisation and tourism development bodies. Similarly, McIntosh et al. (1986) emphasized that the power of relationship among tourism stakeholders is considerably related to community participation in tourism planning and decision-making.

The second component is community participation in tourism operation and management whereby this component can be explained into two aspects (Ashley \& Roe 1998). The first aspect is related to tourism business activities, and the second aspect is related to the management of natural resources and other tourism resources (Ashley \& Roe 1998). Based on the study by Ashley and Roe (1998), there is a passive involvement to full participation by the local community. Moreover, there is involvement at the individual's level to the involvement of all community members. For instance, passive participation is portrayed through the local communities as beneficiaries of tourism development and not as influencers. Meanwhile, active participation is regarded as the knowledge in the management of natural resources and tourism development that need to be empowered towards the local community in order for them to make decision in tourism development. Moreover, the full participation is to ensure the stability from the economic, political, and social benefits perspectives.

The third component is the local community participation in terms of readiness that can be explained in three aspects namely, the knowledge, readiness in commitment, and readiness in resources (Ayu 2014). However, people argued that it is important for relevant theoretical knowledge and practical experience by the local community in ensuring the success of plans in tourism 
Printed by: hidayah_rahman@iium.edu.my. Printing is for personal, private use only. No part of this book may be reproduced or transmitted without publisher's prior permission. Violators will be prosecuted.

development. The local community knowledge is important during the first phase of the planning process. This is supported by Simmons's (1994) study where the low knowledge of tourism amongst local people should be a reason to make the effort in order to encourage the local community to participate in the tourism development process. Kim et al.'s (2014) study in Houay Kaeng Village, Laos has highlighted that among the barrier for the local community's involvement in tourism operation and management is due to having a low level of knowledge and understanding about the tourism development process. This has resulted in low confidence in the local community to involve in tourism development.

In terms of readiness on commitment, a study by Mutambara (2018) concerning Bergville, Kwa-Zulu Natal South Africa as the case study has shown that the rural area is blessed with plenty of natural resources and the natural resources are seen as the tourism products that can boost the quality of life for the local community in this area. Unfortunately, there is no effort from the local authority and its community to develop these natural resources as tourism attractions (Mutambara 2018). This shows that the area is not ready to be developed as a tourism destination because the local community is not ready to fully utilize the tourism resources as the attractions at the place.

Moreover, according to Aref, Redzuan, and Gill (2009), readiness in terms of resources is referred to the ability of the local community to identify potential tourism resources and attractions within their communities as well as their support towards responsible tourism and community development. According to the Report of the World Commission on Environment and Development (2017), the local community has the opportunity of controlling the management of their resources and make decisions for the benefits of the present generation without comprising the organizational structure of the future generation (Donny, Sharon \& Nor 2012). Hence, the local community readiness in terms of resources is a vital component to ensure that they will involve in the tourism planning and development process.

\section{METHODOLOGY}

This study is a qualitative research to explore the readiness and participation of the local community for river-based tourism development in Sabak Awor, Muar. A semi-structured interview question was developed and there were five residents in Sabak Awor Village have participated in this study. This study has implemented the purposeful sampling technique in which the respondents are selected based on different backgrounds and profiles namely, former Head of the village, fishmonger, housewife, unemployed youth, and small business operator. The data collection was conducted from the 17th of October 2019 until the 7th of November 2019.

The semi-structured interview questions were designed based on the components from Thammanjinda's (2013) study. The questions were divided into two sections in which, the first interview section was designed for the local leaders meanwhile, the second section was designed for the local community in Sabak Awor village. Next, the data that has been collected will be classified into themes and sub-themes. The themes are, the readiness of the local, forms of participation, and the impacts of tourism in Sabak Awor village, Muar. Then, the sub-themes are including tourism knowledge, tourism resources, decision-making process and planning, tourism operation and management, benefits, quality of life, employment opportunities, awareness on tourism, household income, accessibility, and infrastructure. The data was transcribed and tabulated to achieve the research objectives.

\section{RESULTS AND DISCUSSION}

Based on the data, five of the respondents emphasised the potential of the river along with Sabak Awor Village as one of the new tourism attractions in Muar for future tourism development. 
Printed by: hidayah_rahman@iium.edu.my. Printing is for personal, private use only. No part of this book may be reproduced or transmitted without publisher's prior permission. Violators will be prosecuted.

\subsection{Aspect one: Readiness}

\subsubsection{Knowledge}

Skills and knowledge are essential components for the local community in order for them to be involved in tourism development. The findings revealed that a low level of knowledge affects the readiness of the local community. First, most of the respondents emphasised the lack of access to tourism information. For instance, one of the respondents from Sabak Awor village stated that “.... I have heard about community-based eco-tourism development programs and other programs that involve the community in a rural area but I'm not sure what the program is all about. So, I decided not to participate in the end." Another resident has shared that there was no clear information given to them about the village planning. Based on Moscardo (2008), tourism knowledge is important in encouraging the local community to participate in tourism development. The finding from this study has shown that the low level of tourism knowledge has discouraged the local community to participate in tourism development in Sabak Awor village.

\subsubsection{Resources}

Tourism resources are the main initiators for tourists to visit an attraction. Attractive tourist resources with a good ambience and a unique value will initiate more tourist movement and consumption. The findings have shown that there are two tourism resources identified in the context of Sabak Awor village namely, natural resources and anthropogenic tourism resources.

First, a male respondent has listed several natural resources in his statement: “...Here, a variety of resources can be found such as a river, types of flora and fauna, and not to forget our symbolic fireflies." This finding also has been supported by another male respondent in which he stated that "... One thing that I like about this village is because we have fireflies that not many know. When talking about fireflies they (tourists) will only remember Kuala Selangor. Also, you can find jellyfish in the river while searching for fireflies during the night-time." The findings had reflected Aref et al's (2009) study in which the locals need to identify potential tourism resources and attraction within their areas.

\subsubsection{Commitment}

Based on the transcribed data, the local's commitment to developing Sabak Awor as a river-based tourism destination has been identified. As said by one of the locals, “ $\ldots$. here already have fireflies tour but the price is high and not many can afford. Since we have locals who can drive their boat especially among the fishmonger why not we offer tourists our services at an affordable price. This can give benefits in terms of increasing their incomes for the community too." Hence, this finding has shown that the locals are committed and ready to upgrade Sabak Awor Village as the new tourism attraction. This finding has supported Ayu's (2014) study on the importance of the local community commitment in the planning and the strategy to develop the area into a tourism destination.

\subsection{Aspect two: Participation}

\subsubsection{Decision making process and planning}

The findings had identified the local community involvement in tourism development and planning in river-based tourism development. One of the respondents has stated that, "... I think because I am considered young and most of the committee members are from the older generation are making me and other youngsters feel that we are not eligible also does not have power in joining meetings until we reached their age." Similarly, the issue of eligibility and power is being highlighted by the female respondent which in her statement that “. . . although I have stated before that I don't have time to involve because of being a housewife, actually that is not the major factor. The major reason is because we as the youngsters feel that we are excluded in public engagement activities because our age, and we don't have a power to voice out just like those who are in the committee members." Moscardo (2015) had stressed the issue of exclusion of the locals to participate in tourism planning, 
Printed by: hidayah_rahman@iium.edu.my. Printing is for personal, private use only. No part of this book may be reproduced or transmitted without publisher's prior permission. Violators will be prosecuted.

Table 1. Summary of the findings for the local community readiness and participation of River-based Tourism Development in Sabak Awor Muar, Johor.

\begin{tabular}{|c|c|c|}
\hline Aspects & Items & Overall Findings \\
\hline \multirow[t]{2}{*}{ Readiness } & Knowledge & $\begin{array}{l}\text { - Low Level of Knowledge } \\
\text { - Lack of access to tourism information } \\
\text { - Level of English education }\end{array}$ \\
\hline & Resources & $\begin{array}{l}\text { - Ability to identify tourism resources } \\
\text { - Natural resources } \\
\text { - Anthropogenic tourism resources ie; folklores, gastronomic. }\end{array}$ \\
\hline \multirow[t]{3}{*}{ Participation } & $\begin{array}{l}\text { Decision-making } \\
\text { Process \& Planning }\end{array}$ & $\begin{array}{l}\text { - Less Participation from the local community } \\
\text { - Tight working schedule and lack of time } \\
\text { - Inadequate Opportunities } \\
\text { - Insufficient chances } \\
\text { - Lack of eligibility and power } \\
\text { - The gap between locals and village leaders }\end{array}$ \\
\hline & $\begin{array}{l}\text { Tourism Operation } \\
\text { and Management }\end{array}$ & $\begin{array}{l}\text { - Involvement of the locals in tourism sector } \\
\text { - Accommodation } \\
\text { - Restaurant } \\
\text { - Ikan Bakar (Seafood) } \\
\text { - Convenience and Souvenir shops } \\
\text { - Boats and speed boat services } \\
\text { - Fireflies tour } \\
\text { - Fishing tour } \\
\text { - Mangrove tour } \\
\text { - Sell sea catches }\end{array}$ \\
\hline & $\begin{array}{l}\text { The benefits of } \\
\text { tourism. }\end{array}$ & $\begin{array}{l}\text { - Opportunity for Small Medium Enterprise Sectors (SMEs), } \\
\text { - Improvement of the basic infrastructure in the village } \\
\text { - Improvement of the social and interpersonal skills } \\
\text { - Waste Management } \\
\text { - Recycling waste } \\
\text { - Management of the river }\end{array}$ \\
\hline
\end{tabular}

hence the findings from this study have shown that there is a limited involvement from a different group of the local community in the decision making process in Sabak Awor Village.

\subsubsection{Tourism operation and management}

Based on the data, the local community in Sabak Awor village is involved in the tourism sector either directly or indirectly in tourism development. An interview with the previous village headman, Tuan $\mathrm{Hj}$ Deris, has explained that the local community in Sabak Awor village is involved in tourism such as operating accommodation, restaurants, convenience and souvenir shops, boat services, fireflies' tours, and fishing tours. A respondent stated "... Locals here used the source of river as their incomes such as from fishing activities, the sea catches are sold to locals that run 'Ikan Bakar' (Seafood) restaurants." Hence, the finding had shown that the local community is indeed involved in the tourism operation and management for Sabak Awor Village.

\subsubsection{Involvement of locals towards the benefits of tourism}

The findings in relation to the local community involvement in sharing the tourism benefits were identified into three aspects which are; how the tourism industry has improved the Small Medium Enterprise Sectors (SMEs), the basic infrastructure in the village, and the local community skills. 
Printed by: hidayah_rahman@iium.edu.my. Printing is for personal, private use only. No part of this book may be reproduced or transmitted without publisher's prior permission. Violators will be prosecuted.

The finding has shown that tourism offers small scale business opportunities compared to other industries. One of the respondents has emphasized on the type of Small Medium Enterprise business in Sabak Awor village in which "... A large number of the local community is involved in the first level of economic activities which are agriculture and fisheries. Most of the villagers are rubber tappers and fisherman, The most important type of businesses are selling fish, sell confectionaries (kuih muih), and open restaurant business such as Seafood restaurant." Interestingly, one respondent shared that his communication skills and tourism knowledge has been improved from the interaction with tourists. Hence, the findings from this study are similar to the study by Hanafiah et al. (2013), in which the local community will gain benefits from participating in tourism development planning.

\subsection{The summary of the findings}

Based on the discussion in previous sections, the local community readiness is viewed into two aspects namely, the knowledge and resources. Meanwhile, the local community participation is viewed into three aspects namely, the decision-making process and planning, tourism operation and management, and benefits of tourism towards the local community. Hence, Table 1 summarises the overall findings of this study.

\section{CONCLUSION}

This study has highlighted the fundamental approach in exploring the readiness of the local community in river-based tourism in Sabak Awor, Muar, Johor, Malaysia. For the local community readiness, there are two aspects that have been assessed. First, tourism knowledge and second is the tourism resources. Furthermore, this study also highlighted the local community participation in river-based tourism development in terms of the decision-making process and planning, tourism operation and management, and local community participation in the benefits of tourism. Based on the present study, a semi-structured interview had been designed to examine the factors of readiness and participation of the local community. This study has contributed to the body of knowledge in terms of readiness and local participation for river-based tourism development in Sabak Awor village, Muar, Johor, Malaysia. The methodological approach of qualitative data analysis based on transcribing the feedback and responds had a huge influence on this study to explore the readiness and participation of the local community for river-based tourism in Sabak Awor Village, Muar, Johor, Malaysia. Therefore, from this technique, this study had the ability to see community participation in a wider context. This study would have a considerable impact on future planning and development, especially for river-based attraction.

\section{REFERENCES}

Aref, F., Redzuan, M., \& Gill, S. S. (2009). Community skill \& knowledge for tourism development. European Journal of Social Sciences, 8(4), 665-671.

Ashley, C., \& Roe, D. (1998). Enhancing Community Involvement in Wildlife Tourism: Issues and Challenges. IIED Wildlife and Development Series, 11, 1-38.

Asyraf, M. K. M., Nor 'aini, Y., \& Suraiyati, R. (2013). Rivers, Lakes, and Swamps: Sustainable Approach towards Ecotourism, (July), 29-31.

Ayu, R. (2014). Sustainable Tourism on Semau Island: Ready or not? Journal of Tourism \& Hospitality, 03(03). https://doi.org/10.4172/2167-0269.1000133

Donny, S \& Mohd Nor, N. (2012). Community-based Tourism (CBT): Local Community Perceptions toward Social and Cultural Impacts

Hamdi, A. E., Maryati, M., \& Shafiq Hamdin, M. (2019). The Potential of Nature Tourism at Muar and Tangkak Districts, Johor, Malaysia. IOP Conference Series: Earth and Environmental Science, 269(1). https://doi.org/10.1088/17551315/269/1/012008 
Printed by: hidayah_rahman@iium.edu.my. Printing is for personal, private use only. No part of this book may be reproduced or transmitted without publisher's prior permission. Violators will be prosecuted.

Hanafiah, M. H., Jamaluddin, M. R., \& Zulkifly, M. I. (2013). Local Community Attitude and Support towards Tourism Development in Tioman Island, Malaysia. Procedia - Social and Behavioral Sciences, 105, 792-800. https://doi.org/10.1016/j.sbspro.2013.11.082

Jawatan Kuasa Keselamatan dan Kemajuan Kampung (JKKK Report, 2015). Laporan JKKK Kampung Sabak Awor, Muar.

Kim, S., Park, E \& Phandanouvong, T. (2014). Barriers to Local Residents' Participation in Community-Based Tourism: Lessons from Houay Kaeng Village in Laos. SHS Web of Conferences. 12. 10.1051.

Kunjuraman, V. (2019). River Tourism: A new tourism product for Malaysia, (January).

McIntosh, R. W., Goeldner, C. R., \& Ritchie, J. R. B. (1995). Tourism: Principles, Practices and Philosophies $(7 \mathrm{ed}$.). New York: John Wiley \& Sons.

Moscardo, G. (2008). Building community capacity for tourism development: Conclusions. Building Community Capacity for Tourism Development. 172-179.

Mutambara, E. (2018). Critical Resources for the Development of Rural Tourism within the greater Bergville area of Kwa-Zulu Natal South Africa. Retrieved from https://www.ajhtl.com/uploads/7/1/6/3/7163688/ article_2_vol_7_5_2018.pdf

Nasarudin, M. H. M., \& Bahar, A. M. A. (2013). River Tourism: A Potential in Pergau River, Jeli, Kelantan. Journal of Tourism, Hospitality and Sports, 1(2009), 1-17.

Prideaux, B., \& Cooper, M. (2009). River tourism. River Tourism. https://doi.org/10.9774/gleaf.9781315680 088_15

Rahmafitria, F., Wirakusuma, R. M., \& Riswandi, A. (2017). Development of Tourism Potential in Watersports Recreation, Santirah River, Pangandaran Regency, Indonesia. People: International Journal of Social Sciences, 3(1). Retrieved from https://grdspublishing.org/index.php/people/article/view/442

Rahman, N. H. A., Abas, S. A., Omar, S. R., \& Jamaludin, M. I. (2020). Exploring the river-based tourism product for Muar River: A tourism opportunity spectrum (TOS) approach. IOP Conf. Series: Earth and Environmental Science, 447(1), 1-7.

Samah, B. A., Sulaiman, M., Shaffril, H. A. M., Hassan, M. S., Othman, M. S., Samah, A. A., \& Ramli, S. A. (2011). Relationship to the River: The case of the Muar River community. American Journal of Envinonmental Sciences, 7(4), 362-369. https://doi.org/10.3844/ajessp.2011.362.369

Shakiry, A.S. (2007) River Tourism: Can Iraq Benefit from Europe's experience? Islamic Tourism Prospects, Islamic Tourism, Issue 8.

Simmons, D. G. (1994). Community Participation in Tourism Development. Tourism Management, 15(2), 98-108. Social. Rural., 40 (2000), pp. 481-496

Thammajinda, R. (2013). Community participation and social capital in tourism planning and management in a Thai context, 300 .

Timothy, D. J. (2002). Tourism and Community Development Issues. In R. Sharpley \& D. J. Telfer (Eds.), Tourism and Development: Concepts and Issues. England: Channel View Publications. 